\title{
Endocrine risk factors for COVID-19: Endogenous and exogenous glucocorticoid excess
}

\author{
Frederick Vogel ${ }^{1}\left[\right.$ [ $\cdot$ Martin Reincke ${ }^{1}[$
}

Accepted: 21 June 2021 / Published online: 9 July 2021

(c) The Author(s) 2021

\begin{abstract}
Patients with endogenous or exogenous glucocorticoid (GC) excess exhibit a range of side effects, including an increased risk of infections. Via both mechanism, immune impairments and cardiometabolic concomitant diseases, patients with GC excess could be at increased risk for COVID-19. The impact on incidence and outcome of a SARS-CoV-2 infection in this population are not yet completely clear. This review aims to compile the data available to date and to discuss the existing literature on this topic. Further we highlight potential effects of SARS-CoV-2 on the hypothalamic-pituitary-adrenal axis as well as the influence of endogenous or exogenous GC excess on SARS-CoV-2 mRNA vaccination. There is growing evidence suggesting an increased risk of infection and severe outcome in patients with high-dose GC therapy after contracting SARS-CoV-2. The few data and case reports on patients with endogenous GC excess and SARS-CoV-2 infection point in a similar direction: chronic GC excess seems to be associated with an unfavorable course of COVID-19. Whether this is mainly a primary immune-mediated effect, or also triggered by the many GC-associated comorbidities in this population, is not yet fully understood. Patients with endogenous or exogenous GC excess should be considered as a vulnerable group during the SARS-CoV-2 pandemic. Regardless of the cause, vaccination and consistent surveillance and control of associated comorbidities are recommended.
\end{abstract}

Keywords COVID-19 · Hypercortisolism · Glucocorticoids · Cortisol · Cushing's syndrome

\section{Introduction}

The novel coronavirus, named severe acute respiratory syndrome coronavirus 2 (SARS-CoV-2), was first identified in January 2020. Since the initial reports of a cluster of pneumonia cases in Wuhan, China, in December 2019, acute infection by SARS-CoV-2, officially named as coronavirus disease-19 (COVID-19), has spread throughout the world [1]. Symptoms and clinical course of SARS-CoV-2 infection are highly variable, ranging from asymptomatic to lethal $[2,3]$. The symptomatology and impairments of COVID-19 primarily affect the respiratory tract, but many other organs are also involved, such as the gastrointestinal tract, liver, kidneys, skin, endocrine organs as well as the musculoskeletal, central nervous and cardiovascular system

Martin Reincke

Martin.Reincke@med.uni-muenchen.de

1 Medizinische Klinik und Poliklinik IV, Klinikum der Universität, Ludwig-Maximilians-Universität München, Munich, Germany
[4-6]. Epidemiological evidence from the first cases of hospitalized COVID-19 patients demonstrated that COVID-19 more likely affects older males with chronic underlying conditions, mainly metabolic, cardiovascular and cerebrovascular diseases [7]. In further studies, older age and a large body of comorbidities have been found to be associated with morbidity and mortality due to COVID-19 [2, 8]. But the underlying mechanisms remain largely unknown [9]. Especially patients with chronic metabolic diseases, like obesity, diabetes, hypertension, cardiovascular and kidney diseases showed a higher risk of acute respiratory distress syndrome (ARDS) and fatal outcome [10]. Administration of dexamethasone has been shown to be effective therapy in patients with respiratory complications due to COVID-19 $[11,12]$. This appears to be partly contradictory, as the use of exogenous glucocorticoids (GCs) is, despite their efficiency in terms of immunomodulation, frequently associated with concomitant metabolic diseases, such as obesity, hypertension, cardiovascular diseases, hepatic steatosis, insulin resistance and type 2 diabetes [13-15]. In patients with endogenous GC excess, a serious endocrine disease 
caused by chronic, autonomous, and excessive secretion of cortisol from the adrenal glands, the metabolic side-effects of GCs are often many times more pronounced. While chronic endogenous hypercortisolism, i.e. endogenous Cushing's syndrome (CS), is a rare disorder with an annual incidence of 2-3/million [16], up to $70 \%$ of patients under GC treatment experience adverse systemic side-effects in the sense of an iatrogenic CS [15, 17]. Regarding the latter, it is estimated that $1-3 \%$ of the population of the United States, United Kingdom or Denmark take GCs for the treatment of inflammatory and autoimmune diseases [18-20]. Beside the metabolic changes, patients with both endogenous and iatrogenic hypercortisolism also have increased risk of various bacterial, viral, fungal and parasitic infections, induced by an immunocompromised state [21-23]. The outcomes of SARS-CoV-2 infection in patients with immune-modulatory therapies are, so far, only partly understood. Understanding the real impact of GC treatment on the frequency and severity of COVID-19 is an important inter-disciplinary issue. In this article, we will review the epidemiology and outcomes of SARS-CoV-2 infections in patients with endogenous and exogenous GC excess based on the literature available to date. Furthermore, we discuss safety and efficacy of SARSCoV-2 mRNA vaccines in patients with GC excess as well as the potential effects of a SARS-CoV-2 infection on the hypothalamic-pituitary-adrenal (HPA) axis.

\section{Risk in exogenous glucocorticoid excess}

Since their discovery in the 1940s and the recognition of the immunosuppressive actions, GCs have been considered one of the most widely used and effective therapies to control inflammatory and autoimmune diseases [24]. Patients receiving chronic oral GCs due to rheumatic diseases are at higher risk for serious infections [25]. Over the past 12 months, since the outbreak of SARS-CoV-2, an unprecedented number of case reports and studies on COVID-19 has been published, and numerous risk factors for severe disease have been identified. Whether or not patients with systemic GC treatment are at an increased risk of SARS-CoV-2 infection and/ or severe outcomes is so far not fully clarified. On the one hand, GCs were discussed theoretically to mitigate hyperimmune reactions responsible for severe disease progression [26]. An enhanced local innate immune defense in respiratory epithelial cells was reported in response to GC exposure, beside the known anti-inflammatory and anti-allergic actions of GCs [27]. However, chronic GC exposure might also increase the risk for infection and/or severe COVID-19 in these patients. Because of the mostly underlying immune system dysfunction, the treatment with immunosuppressive drugs and a higher level of comorbidities, these patients belong to a vulnerable population. Indeed, a meta-analysis of patients with COVID-19 and autoimmune diseases demonstrated in a meta-regression analysis a higher prevalence of COVID-19 in studies with a higher proportion of GC use in patients with autoimmune diseases (regression coefficient: $0.020,95 \%$ CI 0.001 to $0.040, p=0.042$ ) [28]. Due to the heterogeneous studies with different sample sizes, variable diseases included, diagnostic criteria and geographic location, these data should be interpreted with caution. However, there are other studies of patients with autoimmune or inflammatory diseases and GC exposure that have described an increased risk of SARS-CoV-2 infection [26, 29, 30]. Table 1 shows studies with patients under GC treatment and SARS-CoV-2 infection. Concerning the prevalence of SARS-CoV-2 infection, in all three studies mentioned, higher GC doses were associated with a higher risk of contracting SARS-CoV-2. As an exception, Soldevila-Demenech and colleagues reported that women treated with prednisoneequivalent doses $\leq 10 \mathrm{mg}$ per day had a decreased adjusted relative risk for symptoms of SARS-CoV-2. However, since the primary outcome of the study was the clinical diagnosis of COVID-19, and the majority of patients did not undergo a confirmatory SARS-CoV-2 test, these data should be interpreted cautiously. Overall, they also found an increased risk when prednisone-equivalent doses were $>10 \mathrm{mg}$ per day [30].

The risk for hospitalization due to COVID-19 was analyzed by Gianfrancesco and colleagues in a publication from the COVID-19 Global Rheumatology Alliance that analyzed factors associated with hospitalization in 600 cases of COVID-19 in patients with rheumatic diseases [31]. They found, that the use of high-dose GCs $(\geq 10 \mathrm{mg}$ per day of prednisone-equivalent) was associated with hospitalization (adjusted OR 2.05, 95\% CI 1.06 to 3.96, $\mathrm{p}=0.03$ ). Compared to non-hospitalized patients, hospitalized patients due to COVID-19 were more likely to have chronic GC therapy ( $16 \%$ vs $7 \%$ for doses $\geq 10 \mathrm{mg}$ per day, $\mathrm{p}=0.01$ ). In multivariate regression models, age, comorbidities as well as GC therapy prior to the SARS-CoV-2 infection remained associated with the risk of hospitalization [31]. Other studies and case reports of patients with immune-mediated inflammatory diseases are in line with these results and point to similar observations (Table 1): the use of GCs is higher among hospitalized patients, and chronic oral GC use is associated with a higher risk of hospitalization due to COVID-19 in this population [32-35]. In contrast, other studies and case reports of patients with rheumatic diseases showed no direct and significant relation between GC use and the risk of a severe course of disease [36-38]. In general, the outcome for patients with rheumatic diseases does not seem to differ from that of the general population when demographic factors and comorbidities are taken into account [39]. However, since medication use and outcomes are most likely associated [31], GC administration per se already has many unfavorable 


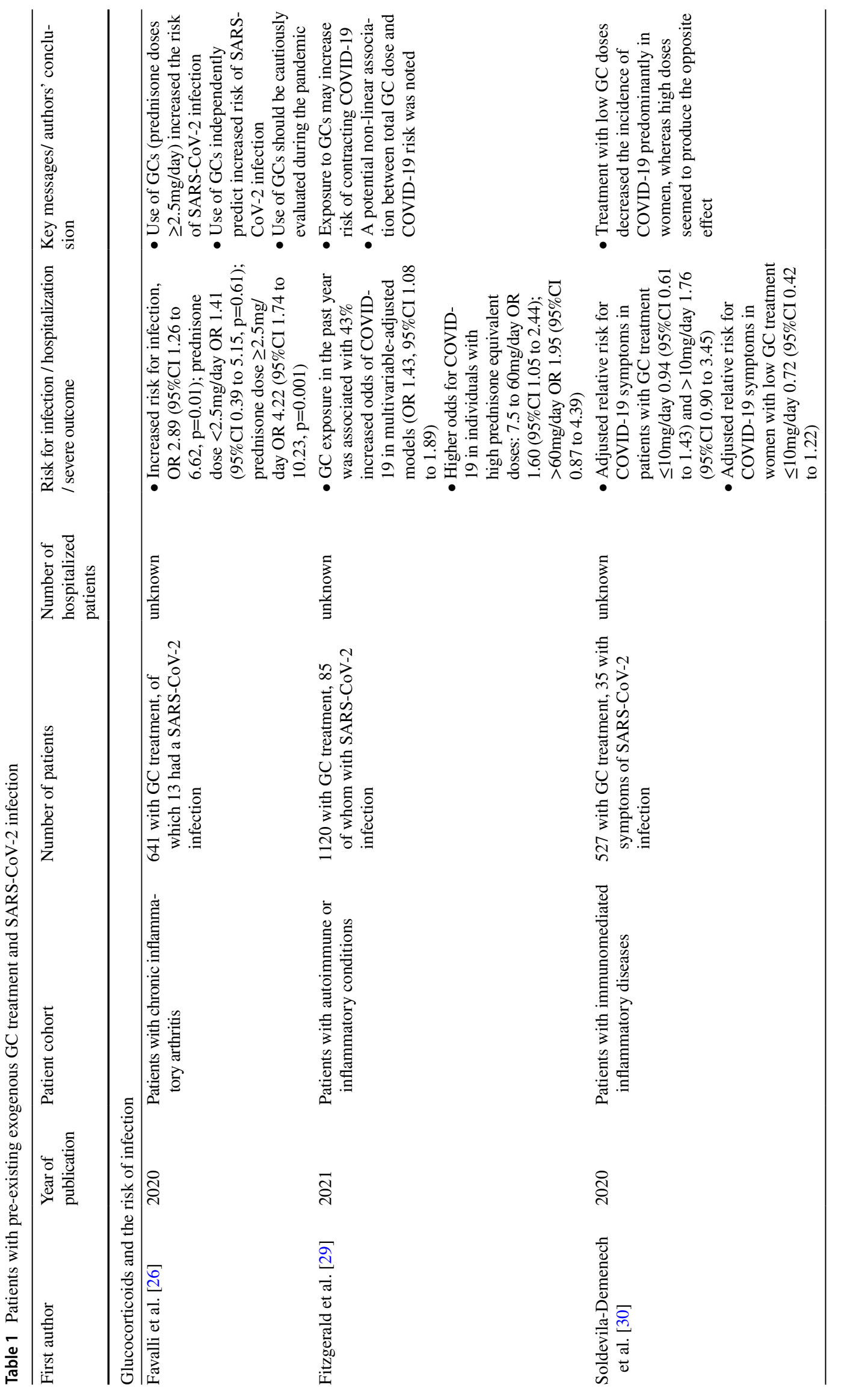




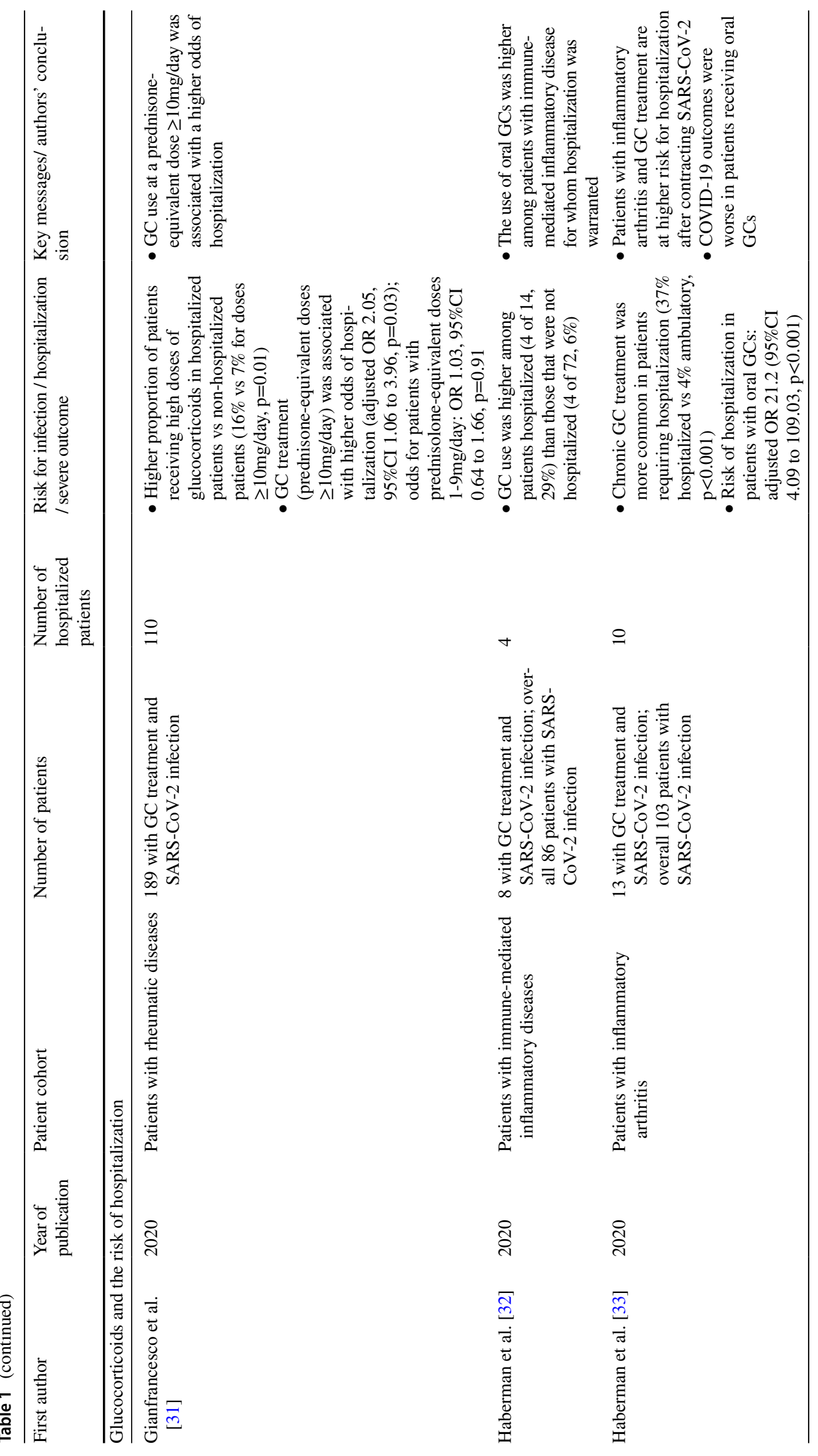




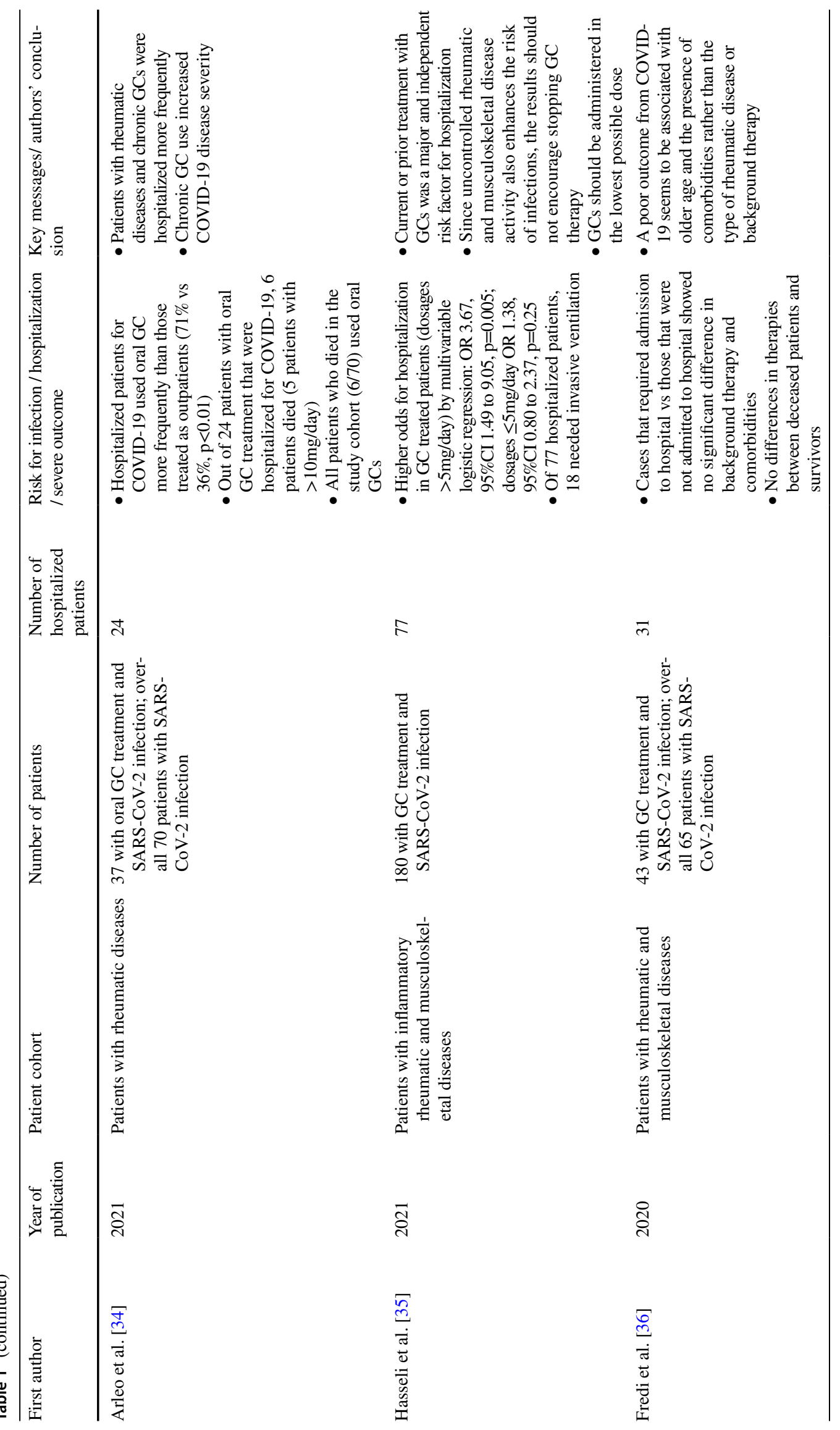




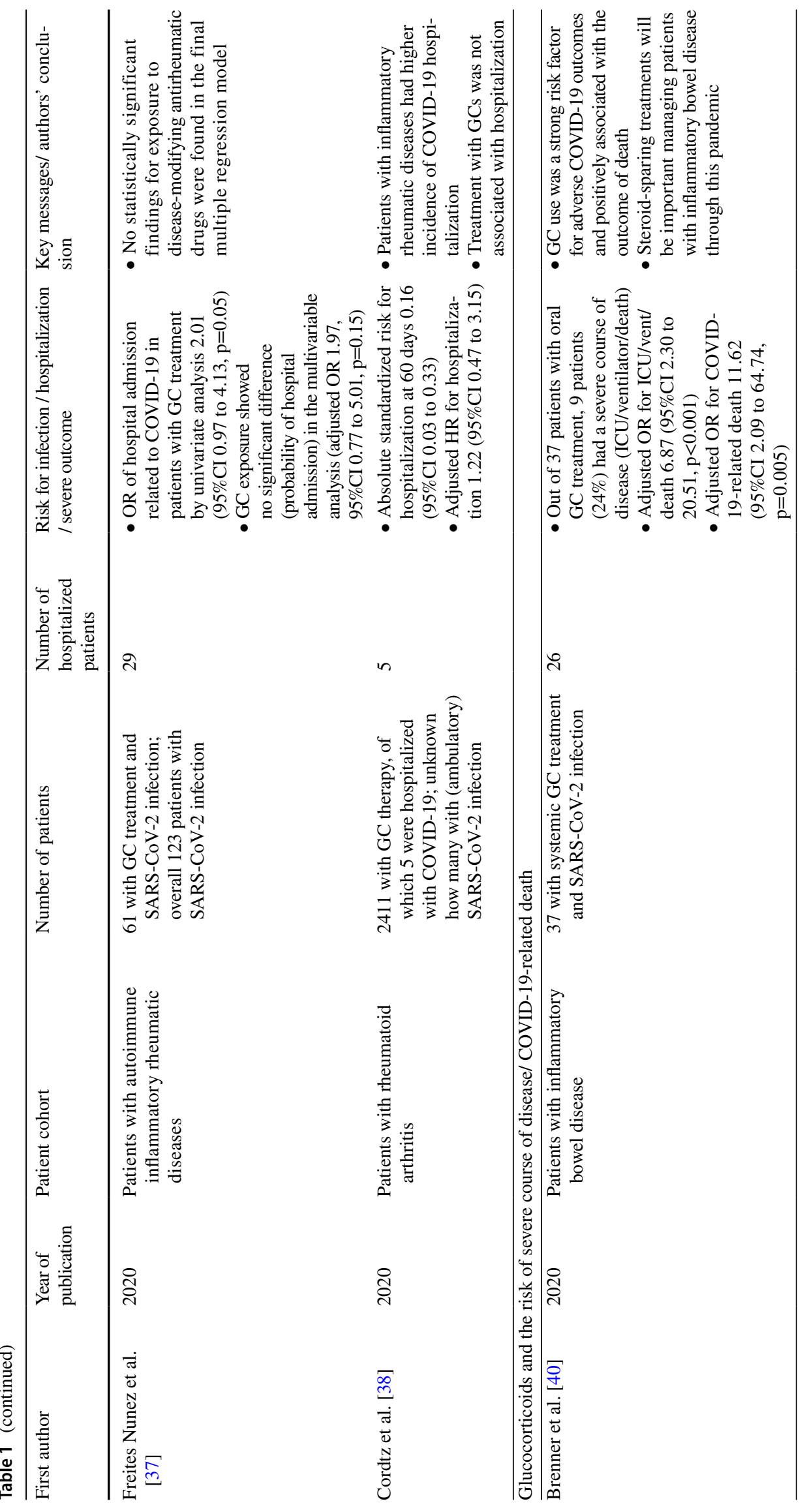




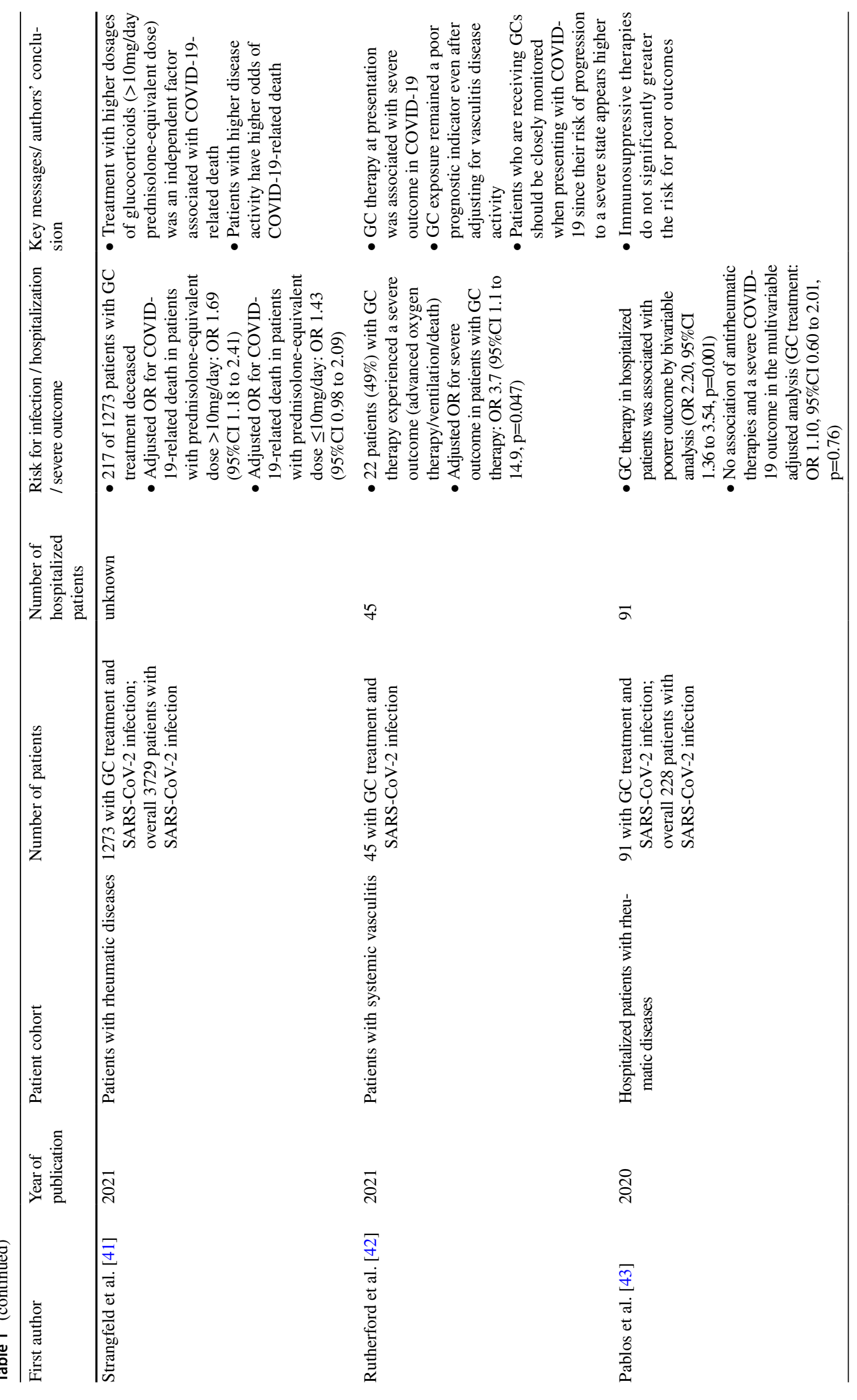




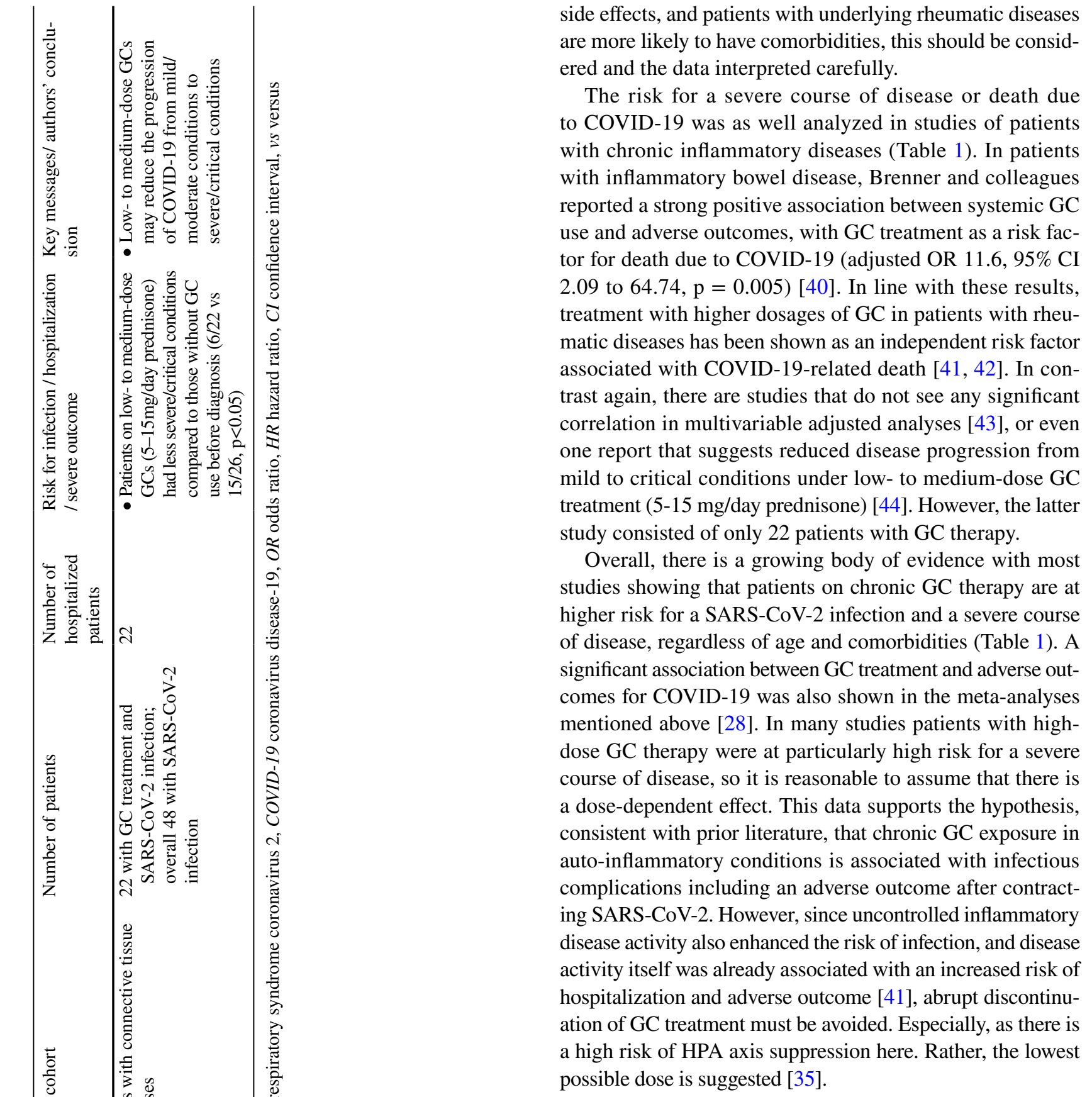

\section{Risk in endogenous glucocorticoid excess}

Endogenous CS leads to a variety of alterations in the immune system and clinical complications such as sepsis and opportunistic infections. The prevalence of infections is increased to $21-51 \%$, as a result of the excessive exposure to endogenous GCs $[45,46]$. The combination of a generalized immunosuppression with impaired immune response and a chronic low-grade inflammatory state is suspected to be responsible for the large number of clinical complications [47]. Pre-existing chronic inflammatory conditions 
are known to increase the risk of COVID-19-related death [10]. Little is known about the risk of SARS-CoV-2 infection or severe disease progression in patients with endogenous CS. Table 2 summarizes the studies and case reports on patients with endogenous CS. Belaya and colleagues recently reported on three patients with ACTH-dependent CS and confirmed SARS-CoV-2 infection [48]. The course of these three patients ranged from asymptomatic to lethal. As the course was particularly severe in a patient with newly diagnosed and florid CS, the authors assumed that the clinical course of COVID-19 might be dependent on severity of hypercortisolism in patients with CS, and that florid CS and COVID-19 are more likely to require emergency care. Two additional manuscripts report single case studies (Table 2): the first one was a 71-year-old man with florid hypercortisolism and past metyrapone therapy, who recovered after one week of isolation [49], the second a 27-year-old woman who was scheduled for pituitary surgery due to Cushing's disease when contracting SARS-CoV-2 [50]. The latter developed COVID-19 pneumonia with a respiratory deterioration and the need for $7 \mathrm{~L} / \mathrm{min}$ oxygen supply by mask, without further risk factors associated with severe COVID-19. After controlling hypercortisolism by a 'block and replace' regime with steroidogenesis inhibitors and hydrocortisone, and a further supportive therapy, the patient improved and was successfully operated one month later. The authors concluded from their case that a multi-disciplinary management with prompt treatment strategies was essential, and that endogenous GC excess could have enhanced the severity of SARS-CoV-2 infection [50].

Table 3 shows published data on serum cortisol concentrations in patients with SARS-CoV-2 infection. Tan and colleagues reported plasma cortisol concentrations in patients hospitalized for COVID-19 within 48 hours after admission [51]. Patients with confirmed COVID-19 had higher plasma cortisol concentrations compared to patients without COVID-19, and cortisol concentrations were associated with a higher mortality in patients with COVID-19 (Table 3) [51, 52]. There is also the hypothesis that endogenous cortisol acts through the activation of unprotected mineralocorticoid receptors and exhibits deleterious effects in COVID19 disease via this mechanism [53,54]. As dexamethasone, unlike cortisol, binds more selectively to the glucocorticoid receptor, suppresses the secretion of endogenous cortisol and exhibits only a weak mineralocorticoid effect, it has been suggested that this could be an additional effective action of dexamethasone in critically ill COVID-19 patients, beside its anti-inflammatory action. Simultaneous medication with mineralocorticoid receptor antagonists was suggested to be evaluated in these patients $[53,55]$. In line with that, glucocorticoid resistance has been hypothesized to contribute to morbidity and mortality in COVID-19, mechanistically via a reduced ability to inhibit the inflammation triggered by
SARS-CoV-2 [56], or via activation of mineralocorticoid receptors, as known in familial glucocorticoid resistance syndromes [57].

\subsection{Considerations for patients with endogenous Cushing's syndrome}

In response to the SARS-CoV-2 pandemic, several recommendations for the clinical guidance of patients with endogenous CS were published [45, 58-60]. These include preventive factors such as video consultations and adherence to social distancing to reduce the risk of infection, as well as diagnostic and treatment recommendations when extensive differential diagnostic testing and/or surgery is not possible [58]. Surgery is the treatment of choice in all causes of CS, but during the pandemic a delay might occur or be appropriate [59]. Therefore, cortisollowering bridging treatment with steroidogenesis inhibitors are recommended in such situations $[45,58,59]$. Due to the fast onset of action and good effectiveness in controlling hypercortisolism, ketoconazole, metyrapone and osilodrostat should be preferred in florid CS for drug therapy during the pandemic [58, 61]. A medical treatment to control hypercortisolism in patients with CS is recommended not only to prevent disease progression but also to correct hypercoagulability and minimize the risk of COVID-19 [50, 58]. Since higher levels of cortisol in 24-hour urine collection are associated with an increased risk of infection, the magnitude of elevation should be taken into account in the therapy concept [59].

As patients with florid CS are immunocompromised, the febrile response in the case of a SARS-CoV-2 infection might be limited. Furthermore, it is suggested that dyspnea might be enhanced due to left ventricular cardiomyopathy and thoracic muscle weakness in case of COVID-19 pneumonia [45]. In hospitalized patients, prolonged antiviral treatment and empirical prophylaxis with broad-spectrum antibiotics should be considered, because of the increased risk of secondary infections (Table 4). Moreover, both florid CS and COVID-19 are associated with hypercoagulability [62-64]. Thus, patients with CS and COVID-19 might have a higher risk of thromboembolism, which is why treatment with low-molecular-weight heparin is recommended, especially for hospitalized, moderately to severely ill patients $[45,58]$. In the case of COVID-19 in a patient with preexisting adrenostatic therapy, stress doses of GCs should be given to prevent critical illness-related corticosteroid insufficiency [58]. There is also a clinical case of a 67-yearold man with Cushing's disease receiving pasireotide and metyrapone, who developed adrenal insufficiency during COVID-19 infection requiring GC replacement therapy [65]. 'Block and replace' regimens can be useful in certain situations $[58,59]$. 


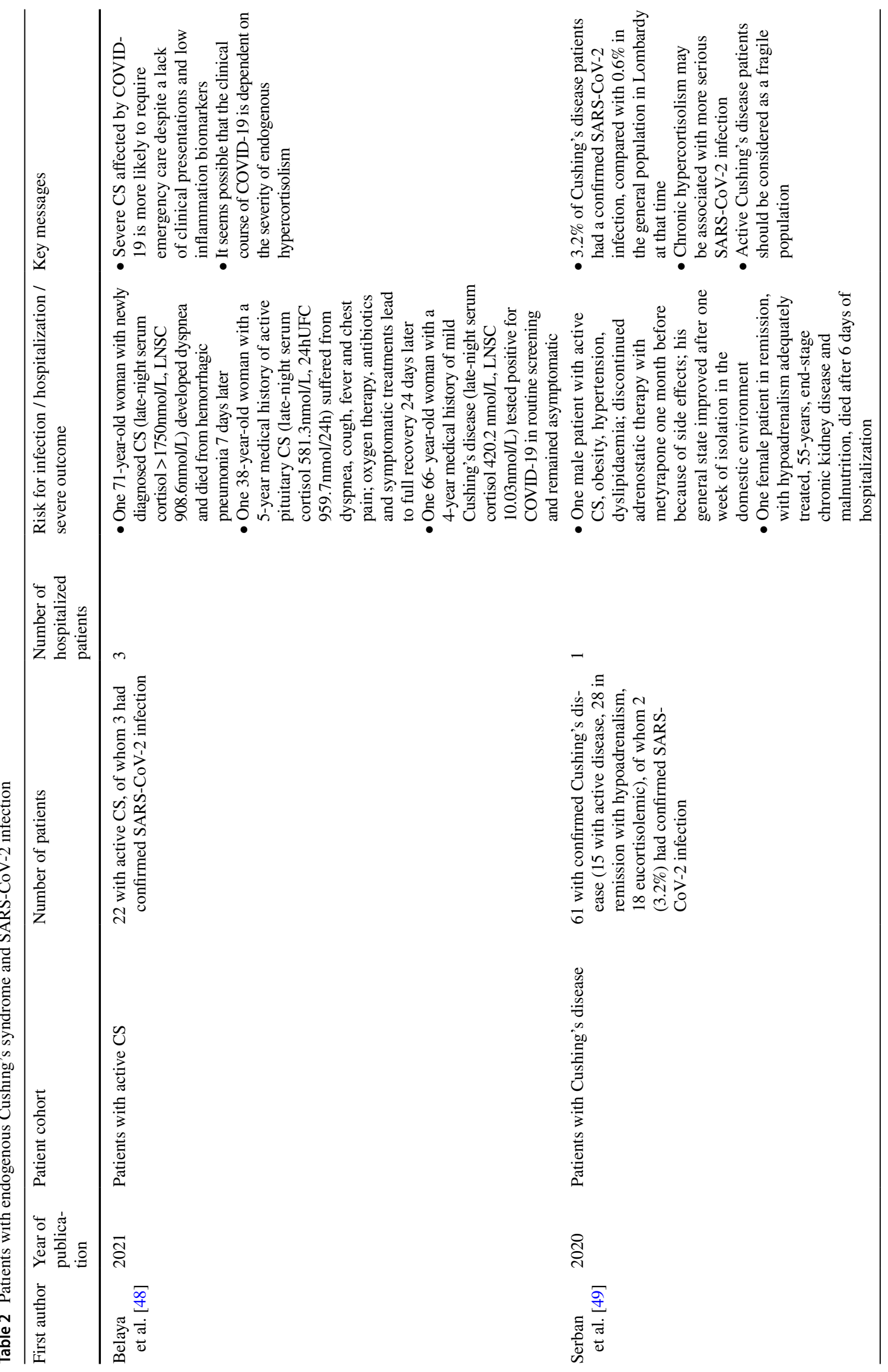




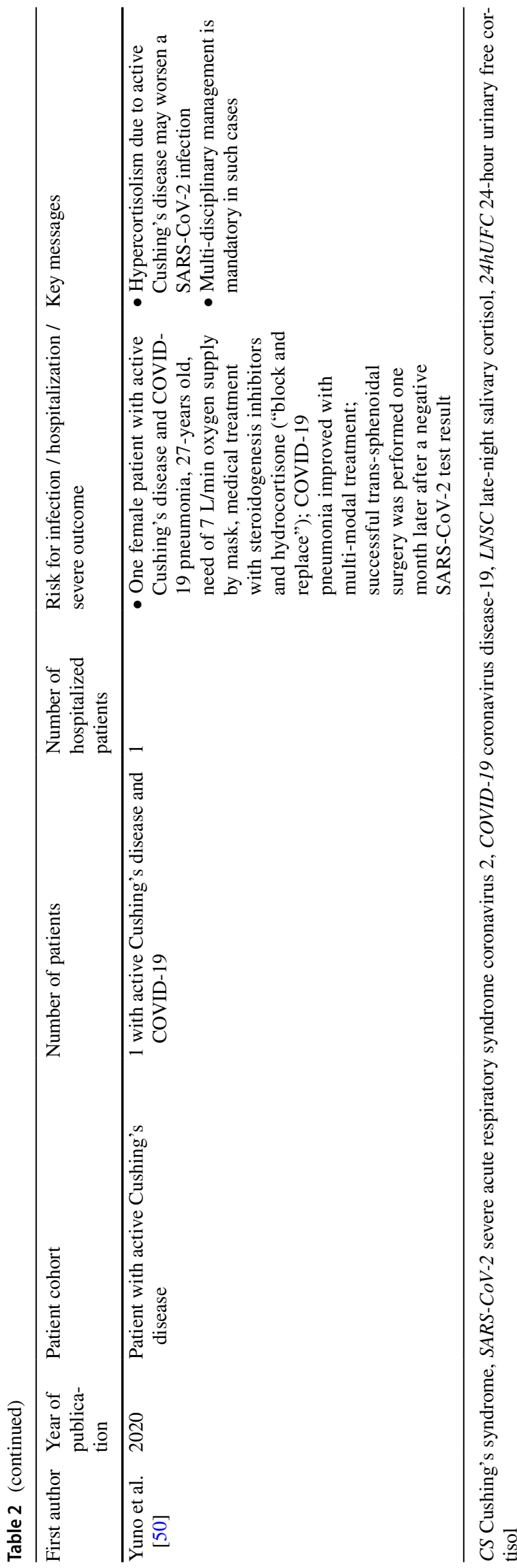

\subsection{Hypercortisolism-associated comorbidities per se might increase the risk for a severe course of disease}

Already in early observational studies it was shown that in patients with obesity, cardiovascular diseases, hypertension, immunodeficiency or diabetes COVID-19 can more easily become a critical illness or cause death [66, 67]. All features that are common in patients with endogenous GC excess [68-70]. The increased cardiovascular risk and the increased susceptibility to severe infections are two leading causes of death in patients with CS [71, 72]. Beside the mentioned immune impairments, GC-induced cardiometabolic changes are common and might additionally increase the risk of a severe course of COVID-19. Table 4 shows known hypercortisolism-associated comorbidities and concomitant risk factors for COVID-19.

Regarding GC-induced comorbidities like hypertension, diabetes, cardiovascular diseases and dyslipidemia, close monitoring and optimization of medical treatment are recommended to improve the eventual clinical course of COVID-19 (Table 4) [45]. Even after successful cure of endogenous CS, patients continue to have increased cardiovascular morbidity and mortality [73, 74]. Also, characteristic features and metabolic comorbidities of endogenous CS like cognitive impairments, obesity, diabetes and muscle weakness were reported to partly persist in the long-term despite biochemical remission [72, 75-78]. Since these conditions increase the risk of COVID-19 with a severe course of disease, even patients in remission for CS should be considered as high-risk population, and GC-associated comorbidities should be treated consistently [45].

\section{SARS-CoV-2 Infection and the Hypothalamic-Pituitary-Adrenal Axis}

Little is known about the effects of COVID-19 on the HPA axis. In general, endogenous GCs are essential for survival under conditions of stress [79]. GCs from the adrenal glands have profound metabolic, cardiovascular and immunological roles in an adequate stress response, elevated cortisol concentrations in critically ill patients are triggered by an activation of the HPA axis [80, 81]. Studies on the impact of COVID-19 on endocrine organs are limited. However, because of the expression of angiotensin-converting enzyme 2 (ACE2) in many endocrine glands [82, 83], endocrine organs are likely to be involved in COVID-19 [6, 84]. Alzahrani and colleagues reported on an impaired adrenocortical response in 28 patients with COVID-19 with plasma cortisol and ACTH concentrations indicating central adrenal insufficiency [85]. The authors found an inverse correlation between disease severity and 
Table 3 Serum cortisol concentrations in patients with SARS-CoV-2 infection

\begin{tabular}{|c|c|c|c|c|c|c|}
\hline First author & $\begin{array}{l}\text { Year of } \\
\text { publication }\end{array}$ & Patient cohort & Number of patients & $\begin{array}{l}\text { Number of } \\
\text { hospitalized } \\
\text { patients }\end{array}$ & $\begin{array}{l}\text { Risk for infection / } \\
\text { hospitalization / severe } \\
\text { outcome }\end{array}$ & Key messages \\
\hline Tan et al. [51] & 2020 & $\begin{array}{l}\text { Patients with } \\
\text { confirmed } \\
\text { diagnosis of } \\
\text { COVID-19 }\end{array}$ & $\begin{array}{l}403 \text { patients with diagnosis } \\
\text { of COVID-19, of whom } \\
112 \text { patients died in the } \\
\text { study period }\end{array}$ & 403 & $\begin{array}{l}\text { - Multivariable } \\
\text { analysis showed } \\
\text { that a doubling of } \\
\text { cortisol concentration } \\
\text { was associated with } \\
\text { a significant } 42 \% \\
\text { increase in the hazard } \\
\text { of mortality }\end{array}$ & $\begin{array}{l}\text { - Patients with COVID- } \\
19 \text { mount a marked and } \\
\text { appropriate acute cortisol } \\
\text { stress response } \\
\text { - High cortisol concentrations } \\
\text { were associated with increased } \\
\text { mortality and a reduced } \\
\text { median survival }\end{array}$ \\
\hline $\begin{array}{l}\text { Ramezani } \\
\text { et al. [52] }\end{array}$ & 2020 & $\begin{array}{l}\text { Patients with } \\
\text { confirmed } \\
\text { diagnosis of } \\
\text { COVID-19 }\end{array}$ & $\begin{array}{l}30 \text { hospitalized patients } \\
\text { with SARS-CoV-2 } \\
\text { infection }\end{array}$ & 30 & $\begin{array}{l}\text { - Higher serum levels of } \\
\text { cortisol were found in } \\
\text { non-survival patients } \\
\text { vs surviving patients } \\
\text { (p=0.017) }\end{array}$ & $\begin{array}{l}\text { - Severe COVID-19 infection } \\
\text { outcomes are more prominent } \\
\text { at a higher level of serum } \\
\text { cortisol }\end{array}$ \\
\hline
\end{tabular}

SARS-CoV-2, severe acute respiratory syndrome coronavirus 2, COVID-19 coronavirus disease-19, vs versus

cortisol or ACTH concentrations. In accordance with these data, compared to non-COVID-19 critically ill patients, lower cortisol concentrations were reported in critically ill patients with COVID-19, among whom $67 \%$ met the criteria for the diagnosis of critical illness-related corticosteroid insufficiency [83]. Contradicting with these findings is the

Table 4 Hypercortisolism-associated comorbidities and the risk of COVID-19

\begin{tabular}{|c|c|c|c|}
\hline Comorbidity in endogenous CS & $\begin{array}{l}\text { Prevalence in } \\
\text { CS }[46,114, \\
115]\end{array}$ & $\begin{array}{l}\text { Reported risk factor } \\
\text { in COVID-19 }\end{array}$ & $\begin{array}{l}\text { Management recommendations during SARS-CoV-2 pandemic [45, } \\
58,61]\end{array}$ \\
\hline Arterial hypertension [69] & $58-85 \%$ & Zhou et al. [2] & $\begin{array}{l}\text { - Hypertensive patients with CS should be considered at high risk for } \\
\text { severe COVID-19 } \\
\text { - Optimization of medical treatment is recommended to improve the } \\
\text { eventual clinical course of COVID-19 }\end{array}$ \\
\hline Diabetes mellitus [70] & $20-47 \%$ & Corona et al. [9] & $\begin{array}{l}\text { - Optimization of medical treatment is recommended to improve the } \\
\text { eventual clinical course of COVID-19 }\end{array}$ \\
\hline Hypercoagulability [63] & $54 \%$ & Levi et al. [62] & $\begin{array}{l}\text { - Strict monitoring of coagulation parameters } \\
\text { - Treatment with low-molecular-weight heparin is recommended, } \\
\text { especially for hospitalized, moderately to severely ill patients }\end{array}$ \\
\hline Immune impairments [45] & $21-51 \%$ & Wu et al. [116] & $\begin{array}{l}\text { - Due to a poor immune response, febrile response in the early phase } \\
\text { might be limited } \\
\text { - Because of the increased risk of secondary infections, prolonged } \\
\text { antiviral treatment and empirical prophylaxis with broad-spectrum } \\
\text { antibiotics should be considered in hospitalized cases of COVID-19 } \\
\text { and florid CS }\end{array}$ \\
\hline Obesity [117] & $32-41 \%$ & Rottoli et al. [118] & $\begin{array}{l}\text { - Patients with CS and visceral obesity should be carefully monitored } \\
\text { in case of COVID-19, due to an increased morbidity and mortality }\end{array}$ \\
\hline $\begin{array}{l}\text { Atherosclerosis/ cardiovascular } \\
\text { diseases [68] }\end{array}$ & $27-31 \%$ & Zou et al. [8] & $\begin{array}{l}\text { - Optimization of medical treatment is recommended to improve the } \\
\text { eventual clinical course of COVID-19 }\end{array}$ \\
\hline Myopathy [75] & $60-82 \%$ & $\begin{array}{l}\text { De Giorgio et al. } \\
\text { [119] }\end{array}$ & $\begin{array}{l}\text { - Dyspnea might be enhanced due to left ventricular cardiomyopathy } \\
\text { and/or thoracic muscle weakness in patients with CS }\end{array}$ \\
\hline Dyslipidemia [120] & $38-71 \%$ & Zuin et al. [121] & $\begin{array}{l}\text { - Optimization of medical treatment is recommended to improve the } \\
\text { eventual clinical course of COVID-19 }\end{array}$ \\
\hline Mental illness [122] & $50-81 \%$ & Barcella et al. [123] & $\begin{array}{l}\text { - As mental illness is associated with an unfavorable outcome in } \\
\text { patients with COVID-19, neuropsychiatric disorders in patients with } \\
\text { CS should be considered and adequately treated }\end{array}$ \\
\hline Obstructive sleep apnea [115] & $50 \%$ & Strausz et al. [124] & $\begin{array}{l}\text { - Consistent therapy is recommended to improve the risk profile and } \\
\text { prevent secondary consequences such as hypertension, reduced } \\
\text { physical performance and further systemic effects }\end{array}$ \\
\hline
\end{tabular}

CS Cushing's syndrome, SARS-CoV-2 severe acute respiratory syndrome coronavirus 2, COVID-19 coronavirus disease-19 
above-mentioned report of Tan and colleagues on higher cortisol concentrations in patients with COVID-19 [51].

Autopsy studies showed frequent microscopic adrenal lesions in patients with severe COVID-19 [86, 87]. However, whether these led to altered cortisol dynamics or an insufficiency is questionable. Already in the context of the previous outbreak of SARS 2003, it has been hypothesized that SARS-CoV inhibits the adrenal stress responses causing a relative adrenocortical insufficiency, via molecular mimicry of ACTH and an immune response that cross reacts with ACTH, and/or direct hypothalamic and pituitary effects $[84,88]$. Data from the previous SARS outbreak even suggested that a substantial proportion of patients (39\%) who recovered from the infection had evidence of central adrenal insufficiency 3 months after recovery. As the HPA axis function of the majority recovered within a year, the authors suggested a reversible hypophysitis or direct hypothalamic injury induced by the virus [89]. Whether the beneficial effects of dexamethasone in the treatment of COVID-19 is due to general supportive benefits of GCs in critical ill patients, mitigation of the cytokine release syndrome and ARDS $[12,90]$, the treatment of undiagnosed adrenal insufficiency [83, 85], or the suppression of endogenous cortisol secretion with reduced effects on mineralocorticoid receptors [53], has to be clarified in the future.

\section{Glucocorticoids and SARS-CoV-2 mRNA vaccines}

Whether patients with endogenous hypercortisolism or GC treatment have a blunted messenger RNA (mRNA) vaccine response is not known. Systemic GC therapy affects both the innate and adaptive immunity. Because of the immunosuppressive actions and the known glucocorticoid receptor expression on all immune cells, the primary concern regarding SARS-CoV-2 vaccines in the setting of GC excess is efficacy. GCs are known to suppress the ability of antigen presenting cells to process antigen and to impair $\mathrm{T}$ cell activation [91]. In animal models, GC exposure was also shown to influence B cell function [92]. Furthermore, there is some evidence suggesting that chronic GC treatment may decrease B-cell counts and specific antibody responses in human [93]. Studies on the functional vaccine outcomes in patients with chronic high-dose GC therapy point toward a potentially impaired vaccine-based immunity with decreased serologic responsiveness in individuals with exogenous GCs [94-96]. However, the decrease of vaccine efficacy in these setting was small, and it has been rather established that patients with chronic GC treatment generate an adequate humoral response to vaccines [97-100].

The use of intraarticular corticosteroids was previously associated with an increased risk for developing influenza despite vaccination [101]. Due to the long-lasting systemic effects of intraarticular corticosteroid injections and the time to establish an effective response of the adaptive immune system, it is suggested to conduct an elective corticosteroid injection no less than two weeks prior and one week following mRNA vaccine dose, whenever possible [102, 103]. However, on the other hand, there are also studies that do not see any connection between vaccine responsiveness and short-term systemic GC administration [100, 104, 105]. To the best of our knowledge, there are no available studies on vaccine response in patients with endogenous GC excess. In dogs with hyperadrenocorticism treated with trilostane, the immune response to canine parvovirus vaccination was comparable with that of healthy dogs [106].

Patients with chronic immunosuppressive therapies have been excluded from the large studies of SARS-CoV-2 mRNA vaccines to date. In a recently published prospective study with 436 transplant recipients and immunosuppressive therapy including tacrolimus $(83 \%)$, corticosteroids (54\%), mycophenolate (66\%), azathioprine (9\%), sirolimus (4\%), and everolimus (2\%), antibodies were detectable in only 76 of 436 participants $(17 \%, 95 \%$ CI $14-21 \%$ ) at a median of 20 days after the first dose of SARS-CoV-2 mRNA vaccine [107]. This is in contrast with the robust early immune response observed in the SARS-CoV-2 mRNA vaccine trials with $100 \%$ seroconversion within 2-3 weeks after immunization with mRNA1273 and BNT162b2 [108, 109]. Despite limitations, such as antibody measurements after only one dose, this study shows that immunocompromised individuals may show a reduced response to mRNA vaccination [107], and could therefore be at a higher risk. Both the mRNA-1273 and BNT162b2 vaccine trials allowed GC use under an oral prednisone equivalent dose of $20 \mathrm{mg}$ per day for up to 14 days, or $280 \mathrm{mg}$ of prednisone equivalent in total [108, 109]. However, so far, no subgroup analysis was provided with participants who were exposed to GCs. Further studies are required for exogenous GCs and other immunosuppressive agents to determine whether these patients can build up a serum titer of anti-SARS-CoV-2 antibodies comparable with individuals not taking immunosuppressive agents. To answer this question, several studies on efficacy and safety of SARS-CoV-2 mRNA vaccination in specific patient populations with immunomodulatory therapies are currently recruiting or planned (ClinicalTrials.gov: amongst others, NCT04848493, NCT04839315, NCT04845997, NCT04824651, NCT04798625).

Noteworthy, all vaccines approved or currently in latestage development, including vaccines based on mRNA, are considered inactivated vaccines. With regard to live vaccination, there are safety concern with systemic GC doses equivalent to $2 \mathrm{mg} / \mathrm{kg}$ or a dose of $20 \mathrm{mg}$ per day of prednisone equivalents for 2 or more weeks [100,110, 111]. However, 
non-live vaccines can be used without restrictions in patients under immunosuppressive therapy [112].

A potentially decreased response to vaccination should not lead to a decision not to vaccinate, and vaccines should not be deferred in these vulnerable patients. As patients with endogenous or exogenous GC excess might be at higher risk for a severe course of COVID-19, immunization is recommended. Thus, it can be assumed that in patients with a higher risk, vaccination even with the result of a lower titer of antibodies is better than no vaccination. Depending on further studies on the immune response, repeated immunization after the period of altered immunocompetence, such as florid endogenous CS or high-dose GC treatment, may be necessary after achieving remission.

\section{Summary and Conclusion}

There is growing evidence that patients under especially high doses of exogenous GC or during endogenous GC excess exhibit an increased risk for SARS-CoV-2 infection and for a severe course of COVID-19. Therefore, in patients with higher doses of exogenous GCs, the lowest possible dose is recommended to control the underlying inflammatory disease. In patients with endogenous CS, adequate control of hypercortisolism is recommended, as increased risk has been associated with the level of cortisol excess. Moreover, good monitoring of metabolic and cardiovascular comorbidities seems particularly important to ameliorate the risk profile of patients with GC excess.

Many questions about the relation between SARS-CoV-2 and endogenous or exogenous GC excess remain unanswered. Further studies are required to understand the risk of these patients as well as the long-term effects of COVID19 in this population. The immediate collection of data in the SARS-CoV-2 pandemic is important to answer key pressing questions. International collaboration between specialists appears to be of great importance for certain patient groups in order to obtain valid data [113]. However, current limitations should be taken into account in the interpretation of studies and case reports. In particular selection bias and confounding are important to consider [39]. We want to acknowledge that our recommendations are based on the aforementioned and currently available data and evidence, and that it has to be updated based on ongoing data.

Funding Open Access funding enabled and organized by Projekt DEAL. This work is part of the German Cushing's Registry CUSTODES and has been supported by a grant from the Else KrönerFresenius Stiftung to M.R. (2012_A103 and 2015_A228). M.R. is supported by the Deutsche Forschungsgemeinschaft (DFG, German Research Foundation, Projektnummer: 314061271-TRR 205). F.V. is supported by the Deutsche Forschungsgemeinschaft (DFG, German
Research Foundation, 413635475) and the Munich Clinician Scientist Program (MCSP) of the LMU München.

\section{Declarations}

Conflicts of interest The authors have nothing to disclose.

Open Access This article is licensed under a Creative Commons Attribution 4.0 International License, which permits use, sharing, adaptation, distribution and reproduction in any medium or format, as long as you give appropriate credit to the original author(s) and the source, provide a link to the Creative Commons licence, and indicate if changes were made. The images or other third party material in this article are included in the article's Creative Commons licence, unless indicated otherwise in a credit line to the material. If material is not included in the article's Creative Commons licence and your intended use is not permitted by statutory regulation or exceeds the permitted use, you will need to obtain permission directly from the copyright holder. To view a copy of this licence, visit http://creativecommons.org/licenses/by/4.0/.

\section{References}

1. Carvalho T, Krammer F, Iwasaki A. The first 12 months of COVID-19: a timeline of immunological insights. Nat Rev Immunol. 2021.

2. Zhou F, Yu T, Du R, Fan G, Liu Y, Liu Z, et al. Clinical course and risk factors for mortality of adult inpatients with COVID19 in Wuhan, China: a retrospective cohort study. Lancet. 2020;395(10229):1054-62.

3. Guan WJ, Ni ZY, Hu Y, Liang WH, Ou CQ, He JX, et al. Clinical Characteristics of Coronavirus Disease 2019 in China. N Engl J Med. 2020;382(18):1708-20.

4. Wan S, Xiang Y, Fang W, Zheng Y, Li B, Hu Y, et al. Clinical features and treatment of COVID-19 patients in northeast Chongqing. J Med Virol. 2020;92(7):797-806.

5. Madjid M, Safavi-Naeini P, Solomon SD, Vardeny O. Potential Effects of Coronaviruses on the Cardiovascular System: A Review. JAMA Cardiol. 2020;5(7):831-40.

6. Gavriatopoulou M, Korompoki E, Fotiou D, NtanasisStathopoulos I, Psaltopoulou T, Kastritis E, et al. Organspecific manifestations of COVID-19 infection. Clin Exp Med. 2020;20(4):493-506.

7. Chen N, Zhou M, Dong X, Qu J, Gong F, Han Y, et al. Epidemiological and clinical characteristics of 99 cases of 2019 novel coronavirus pneumonia in Wuhan, China: a descriptive study. Lancet. 2020;395(10223):507-13.

8. Zou L, Dai L, Zhang Y, Fu W, Gao Y, Zhang Z, et al. Clinical Characteristics and Risk Factors for Disease Severity and Death in Patients With Coronavirus Disease 2019 in Wuhan, China. Front Med (Lausanne). 2020;7:532.

9. Corona G, Pizzocaro A, Vena W, Rastrelli G, Semeraro F, Isidori AM, et al. Diabetes is most important cause for mortality in COVID-19 hospitalized patients: Systematic review and meta-analysis. Rev Endocr Metab Disord. 2021.

10. Martins-Filho PR, Tavares CSS, Santos VS. Factors associated with mortality in patients with COVID-19. A quantitative evidence synthesis of clinical and laboratory data. Eur J Intern Med. 2020;76:97-9.

11. Nissen CB, Sciascia S, de Andrade D, Atsumi T, Bruce IN, Cron RQ, et al. The role of antirheumatics in patients with COVID-19. Lancet Rheumatol. 2021. 
12. Group RC, Horby P, Lim WS, Emberson JR, Mafham M, Bell JL, et al. Dexamethasone in Hospitalized Patients with Covid19. N Engl J Med. 2021;384(8):693-704.

13. Wei L, MacDonald TM, Walker BR. Taking glucocorticoids by prescription is associated with subsequent cardiovascular disease. Ann Intern Med. 2004;141(10):764-70.

14. Fardet L, Petersen I, Nazareth I. Risk of cardiovascular events in people prescribed glucocorticoids with iatrogenic Cushing's syndrome: cohort study. BMJ. 2012;345:e4928.

15. Fardet L, Flahault A, Kettaneh A, Tiev KP, Genereau T, Toledano $\mathrm{C}$, et al. Corticosteroid-induced clinical adverse events: frequency, risk factors and patient's opinion. Br J Dermatol. 2007;157(1):142-8.

16. Steffensen C, Bak AM, Rubeck KZ, Jorgensen JO. Epidemiology of Cushing's syndrome. Neuroendocrinology. 2010;92(Suppl 1):1-5.

17. Morgan SA, McCabe EL, Gathercole LL, Hassan-Smith ZK, Larner DP, Bujalska IJ, et al. 11beta-HSD1 is the major regulator of the tissue-specific effects of circulating glucocorticoid excess. Proc Natl Acad Sci U S A. 2014;111(24):E2482-91.

18. van Staa TP, Leufkens HG, Abenhaim L, Begaud B, Zhang B, Cooper C. Use of oral corticosteroids in the United Kingdom. QJM. 2000;93(2):105-11.

19. Overman RA, Yeh JY, Deal CL. Prevalence of oral glucocorticoid usage in the United States: a general population perspective. Arthritis Care Res (Hoboken). 2013;65(2):294-8.

20. Reincke M. Metformin: the white knight fighting corticosteroid side-effects. Lancet Diabetes Endocrinol. 2020;8(4):258-9.

21. Fareau GG, Vassilopoulou-Sellin R. Hypercortisolemia and infection. Infect Dis Clin North Am. 2007;21(3):639-57, viii.

22. Dussauze H, Bourgault I, Doleris LM, Prinseau J, Baglin A, Hanslik T. Systemic corticosteroid treatment and risk of infectious diseases. Rev Med Interne. 2007;28(12):841-51.

23. Lionakis MS, Kontoyiannis DP. Glucocorticoids and invasive fungal infections. Lancet. 2003;362(9398):1828-38.

24. Coutinho AE, Chapman KE. The anti-inflammatory and immunosuppressive effects of glucocorticoids, recent developments and mechanistic insights. Mol Cell Endocrinol. 2011;335(1):2-13.

25. Dixon WG, Abrahamowicz M, Beauchamp ME, Ray DW, Bernatsky S, Suissa S, et al. Immediate and delayed impact of oral glucocorticoid therapy on risk of serious infection in older patients with rheumatoid arthritis: a nested case-control analysis. Ann Rheum Dis. 2012;71(7):1128-33.

26. Favalli EG, Bugatti S, Klersy C, Biggioggero M, Rossi S, De Lucia $\mathrm{O}$, et al. Impact of corticosteroids and immunosuppressive therapies on symptomatic SARS-CoV-2 infection in a large cohort of patients with chronic inflammatory arthritis. Arthritis Res Ther. 2020;22(1):290.

27. Zhang N, Truong-Tran QA, Tancowny B, Harris KE, Schleimer RP. Glucocorticoids enhance or spare innate immunity: effects in airway epithelium are mediated by CCAAT/enhancer binding proteins. J Immunol. 2007;179(1):578-89.

28. Akiyama S, Hamdeh S, Micic D, Sakuraba A. Prevalence and clinical outcomes of COVID-19 in patients with autoimmune diseases: a systematic review and meta-analysis. Ann Rheum Dis. 2020.

29. Fitzgerald KC, Mecoli CA, Douglas M, Harris S, Aravidis B, Albayda J, et al. Risk Factors for Infection and Health Impacts of the Covid-19 Pandemic in People with Autoimmune Diseases. medRxiv. 2021.

30. Soldevila-Domenech N, Tio L, Llorente-Onaindia J, MartinGarcia E, Nebot P, de la Torre R, et al. COVID-19 Incidence in Patients With Immunomediated Inflammatory Diseases: Influence of Immunosuppressant Treatments. Front Pharmacol. 2020;11:583260.
31. Gianfrancesco M, Hyrich KL, Al-Adely S, Carmona L, Danila MI, Gossec L, et al. Characteristics associated with hospitalisation for COVID-19 in people with rheumatic disease: data from the COVID-19 Global Rheumatology Alliance physicianreported registry. Ann Rheum Dis. 2020;79(7):859-66.

32. Haberman R, Axelrad J, Chen A, Castillo R, Yan D, Izmirly P, et al. Covid-19 in Immune-Mediated Inflammatory Diseases Case Series from New York. N Engl J Med. 2020;383(1):85-8.

33. Haberman RH, Castillo R, Chen A, Yan D, Ramirez D, Sekar V, et al. COVID-19 in Patients With Inflammatory Arthritis: A Prospective Study on the Effects of Comorbidities and DiseaseModifying Antirheumatic Drugs on Clinical Outcomes. Arthritis Rheumatol. 2020;72(12):1981-9.

34. Arleo T, Tong D, Shabto J, O'Keefe G, Khosroshahi A. Clinical course and outcomes of COVID-19 in rheumatic disease patients: a case cohort study with a diverse population. Clin Rheumatol. 2021.

35. Hasseli R, Mueller-Ladner U, Hoyer BF, Krause A, Lorenz HM, Pfeil A, et al. Older age, comorbidity, glucocorticoid use and disease activity are risk factors for COVID-19 hospitalisation in patients with inflammatory rheumatic and musculoskeletal diseases. RMD Open. 2021;7(1).

36. Fredi M, Cavazzana I, Moschetti L, Andreoli L, Franceschini F, Brescia Rheumatology C-SG. COVID-19 in patients with rheumatic diseases in northern Italy: a single-centre observational and case-control study. Lancet Rheumatol. 2020;2(9):e549-e56.

37. Freites Nunez DD, Leon L, Mucientes A, Rodriguez-Rodriguez L, Font Urgelles J, Madrid Garcia A, et al. Risk factors for hospital admissions related to COVID-19 in patients with autoimmune inflammatory rheumatic diseases. Ann Rheum Dis. 2020;79(11):1393-9.

38. Cordtz R, Lindhardsen J, Soussi BG, Vela J, Uhrenholt L, Westermann R, et al. Incidence and severeness of COVID-19 hospitalisation in patients with inflammatory rheumatic disease: a nationwide cohort study from Denmark. Rheumatology (Oxford). 2020.

39. Grainger R, Machado PM, Robinson PC. Novel coronavirus disease-2019 (COVID-19) in people with rheumatic disease: Epidemiology and outcomes. Best Pract Res Clin Rheumatol. 2020:101657.

40. Brenner EJ, Ungaro RC, Gearry RB, Kaplan GG, Kissous-Hunt $\mathrm{M}$, Lewis JD, et al. Corticosteroids, But Not TNF Antagonists, Are Associated With Adverse COVID-19 Outcomes in Patients With Inflammatory Bowel Diseases: Results From an International Registry. Gastroenterology. 2020;159(2):481-91 e3.

41. Strangfeld A, Schafer M, Gianfrancesco MA, Lawson-Tovey S, Liew JW, Ljung L, et al. Factors associated with COVID19-related death in people with rheumatic diseases: results from the COVID-19 Global Rheumatology Alliance physicianreported registry. Ann Rheum Dis. 2021.

42. Rutherford MA, Scott J, Karabayas M, Antonelou M, Gopaluni S, Gray D, et al. Risk factors for severe outcomes in patients with systemic vasculitis \& COVID-19: a bi-national registry-based cohort study. Arthritis Rheumatol. 2021.

43. Pablos JL, Galindo M, Carmona L, Lledo A, Retuerto M, Blanco $\mathrm{R}$, et al. Clinical outcomes of hospitalised patients with COVID19 and chronic inflammatory and autoimmune rheumatic diseases: a multicentric matched cohort study. Ann Rheum Dis. 2020;79(12):1544-9.

44. Ye C, Zhong J, Cai S, Dong L, Li C, Hou X, et al. COVID-19 infection in patients with connective tissue disease: A multicity study in Hubei province. China MedComm (Beijing). 2021;2(1):82-90.

45. Pivonello R, Ferrigno R, Isidori AM, Biller BMK, Grossman AB, Colao A. COVID-19 and Cushing's syndrome: recommendations for a special population with endogenous glucocorticoid excess. Lancet Diabetes Endocrinol. 2020;8(8):654-6. 
46. Cain DW, Cidlowski JA. Immune regulation by glucocorticoids. Nat Rev Immunol. 2017;17(4):233-47.

47. Hasenmajer V, Sbardella E, Sciarra F, Minnetti M, Isidori AM, Venneri MA. The Immune System in Cushing's Syndrome. Trends Endocrinol Metab. 2020;31(9):655-69.

48. Belaya Z, Golounina O, Melnichenko G, Tarbaeva N, Pashkova E, Gorokhov M, et al. Clinical course and outcome of patients with ACTH-dependent Cushing's syndrome infected with novel coronavirus disease-19 (COVID-19): case presentations. Endocrine. 2021.

49. Serban AL, Ferrante E, Carosi G, Indirli R, Arosio M, Mantovani G. COVID-19 in Cushing disease: experience of a single tertiary centre in Lombardy. J Endocrinol Invest. 2020.

50. Yuno A, Kenmotsu Y, Takahashi Y, Nomoto H, Kameda H, Cho KY, et al. Successful management of a patient with active Cushing's disease complicated with coronavirus disease 2019 (COVID-19) pneumonia. Endocr J. 2020.

51. Tan T, Khoo B, Mills EG, Phylactou M, Patel B, Eng PC, et al. Association between high serum total cortisol concentrations and mortality from COVID-19. Lancet Diabetes Endocrinol. 2020;8(8):659-60.

52. Ramezani M, Simani L, Karimialavijeh E, Rezaei O, Hajiesmaeili M, Pakdaman H. The Role of Anxiety and Cortisol in Outcomes of Patients With Covid-19. Basic Clin Neurosci. 2020;11(2):179-84.

53. Edwards C. New Horizons: Does Mineralocorticoid Receptor Activation by Cortisol Cause ATP Release and COVID-19 Complications? J Clin Endocrinol Metab. 2021;106(3):622-35.

54. Funder JW. Aldosterone and Mineralocorticoid ReceptorsPhysiology and Pathophysiology. Int J Mol Sci. 2017;18(5).

55. Villar J, Ferrando C, Martinez D, Ambros A, Munoz T, Soler JA, et al. Dexamethasone treatment for the acute respiratory distress syndrome: a multicentre, randomised controlled trial. Lancet Respir Med. 2020;8(3):267-76.

56. Karan A, Ali K, Rambaran K, Del Corral P, Sakhamuri S, Teelucksingh S. COVID-19 and ethnicity: Does reduced responsiveness to glucocorticoids explain the more aggressive nature of disease among minorities? Med Hypotheses. 2020;144:110220.

57. Charmandari E, Kino T, Chrousos GP. Familial/sporadic glucocorticoid resistance: clinical phenotype and molecular mechanisms. Ann N Y Acad Sci. 2004;1024:168-81.

58. Newell-Price J, Nieman LK, Reincke M, Tabarin A. ENDOCRINOLOGY IN THE TIME OF COVID-19: Management of Cushing's syndrome. Eur J Endocrinol. 2020;183(1):G1-7.

59. Fleseriu M, Buchfelder M, Cetas JS, Fazeli PK, Mallea-Gil SM, Gurnell M, et al. Pituitary society guidance: pituitary disease management and patient care recommendations during the COVID-19 pandemic-an international perspective. Pituitary. 2020;23(4):327-37.

60. Yuen KCJ, Blevins LS Jr, Findling JW. Important Management Considerations In Patients With Pituitary Disorders During The Time Of The Covid-19 Pandemic. Endocr Pract. 2020;26(8):915-22.

61. Guarnotta V, Ferrigno R, Martino M, Barbot M, Isidori AM, Scaroni C, et al. Glucocorticoid excess and COVID-19 disease. Rev Endocr Metab Disord. 2020.

62. Levi M, Thachil J, Iba T, Levy JH. Coagulation abnormalities and thrombosis in patients with COVID-19. Lancet Haematol. 2020;7(6): $438-40$.

63. Wagner J, Langlois F, Lim DST, McCartney S, Fleseriu M. Hypercoagulability and Risk of Venous Thromboembolic Events in Endogenous Cushing's Syndrome: A Systematic Meta-Analysis. Front Endocrinol (Lausanne). 2018;9:805.

64. St-Jean M, Lim DST, Langlois F. Hypercoagulability in Cushing's syndrome: From arterial to venous disease. Best Pract Res Clin Endocrinol Metab. 2021:101496.
65. Beretta F, Dassie F, Parolin M, Boscari F, Barbot M, Busetto $\mathrm{L}$, et al. Practical Considerations for the Management of Cushing's Disease and COVID-19: A Case Report. Front Endocrinol (Lausanne). 2020;11:554.

66. Huang C, Wang Y, Li X, Ren L, Zhao J, Hu Y, et al. Clinical features of patients infected with 2019 novel coronavirus in Wuhan. China Lancet. 2020;395(10223):497-506.

67. Kakodkar P, Kaka N, Baig MN. A Comprehensive Literature Review on the Clinical Presentation, and Management of the Pandemic Coronavirus Disease 2019 (COVID-19). Cureus. 2020;12(4):e7560.

68. De Leo M, Pivonello R, Auriemma RS, Cozzolino A, Vitale P, Simeoli C, et al. Cardiovascular disease in Cushing's syndrome: heart versus vasculature. Neuroendocrinology. 2010;92(Suppl 1):50-4.

69. Isidori AM, Graziadio C, Paragliola RM, Cozzolino A, Ambrogio AG, Colao A, et al. The hypertension of Cushing's syndrome: controversies in the pathophysiology and focus on cardiovascular complications. J Hypertens. 2015;33(1):44-60.

70. Ferrau F, Korbonits M. Metabolic comorbidities in Cushing's syndrome. Eur J Endocrinol. 2015;173(4):M133-57.

71. Ragnarsson O, Olsson DS, Papakokkinou E, Chantzichristos D, Dahlqvist P, Segerstedt E, et al. Overall and Disease-Specific Mortality in Patients With Cushing Disease: A Swedish Nationwide Study. J Clin Endocrinol Metab. 2019;104(6):2375-84.

72. Pivonello R, Isidori AM, De Martino MC, Newell-Price J, Biller BM, Colao A. Complications of Cushing's syndrome: state of the art. Lancet Diabetes Endocrinol. 2016;4(7):611-29.

73. Clayton RN, Jones PW, Reulen RC, Stewart PM, Hassan-Smith ZK, Ntali G, et al. Mortality in patients with Cushing's disease more than 10 years after remission: a multicentre, multinational, retrospective cohort study. Lancet Diabetes Endocrinol. 2016;4(7):569-76.

74. Colao A, Pivonello R, Spiezia S, Faggiano A, Ferone D, Filippella $\mathrm{M}$, et al. Persistence of increased cardiovascular risk in patients with Cushing's disease after five years of successful cure. J Clin Endocrinol Metab. 1999;84(8):2664-72.

75. Vogel F, Braun LT, Rubinstein G, Zopp S, Kunzel H, Strasding $\mathrm{F}$, et al. Persisting muscle dysfunction in Cushing's syndrome despite biochemical remission. J Clin Endocrinol Metab. 2020.

76. Ragnarsson O, Berglund P, Eder DN, Johannsson G. Long-term cognitive impairments and attentional deficits in patients with Cushing's disease and cortisol-producing adrenal adenoma in remission. J Clin Endocrinol Metab. 2012;97(9):E1640-8.

77. Ragnarsson O, Glad CA, Bergthorsdottir R, Almqvist EG, Ekerstad E, Widell H, et al. Body composition and bone mineral density in women with Cushing's syndrome in remission and the association with common genetic variants influencing glucocorticoid sensitivity. Eur J Endocrinol. 2015;172(1):1-10.

78. Espinosa-de-Los-Monteros AL, Sosa E, Martinez N, Mercado M. Persistence of Cushing's disease symptoms and comorbidities after surgical cure: a long-term, integral evaluation. Endocr Pract. 2013;19(2):252-8.

79. Berger I, Werdermann M, Bornstein SR, Steenblock C. The adrenal gland in stress - Adaptation on a cellular level. J Steroid Biochem Mol Biol. 2019;190:198-206.

80. Sapolsky RM, Romero LM, Munck AU. How do glucocorticoids influence stress responses? Integrating permissive, suppressive, stimulatory, and preparative actions. Endocr Rev. 2000;21(1):55-89.

81. Peeters B, Boonen E, Langouche L, Van den Berghe G. The HPA axis response to critical illness: New study results with diagnostic and therapeutic implications. Mol Cell Endocrinol. 2015;408:235-40. 
82. Hamming I, Timens W, Bulthuis ML, Lely AT, Navis G, van Goor $\mathrm{H}$. Tissue distribution of ACE2 protein, the functional receptor for SARS coronavirus. A first step in understanding SARS pathogenesis. J Pathol. 2004;203(2):631-7.

83. Mao Y, Xu B, Guan W, Xu D, Li F, Ren R, et al. The Adrenal Cortex, an Underestimated Site of SARS-CoV-2 Infection. Front Endocrinol (Lausanne). 2020;11:593179.

84. Pal R. COVID-19, hypothalamo-pituitary-adrenal axis and clinical implications. Endocrine. 2020;68(2):251-2.

85. Alzahrani AS, Mukhtar N, Aljomaiah A, Aljamei H, Bakhsh A, Alsudani N, et al. The Impact of COVID-19 Viral Infection on the Hypothalamic-Pituitary-Adrenal Axis. Endocr Pract. 2021;27(2):83-9.

86. Santana MF, Borba MGS, Baia-da-Silva DC, Val F, Alexandre MAA, Brito-Sousa JD, et al. Case Report: Adrenal Pathology Findings in Severe COVID-19: An Autopsy Study. Am J Trop Med Hyg. 2020;103(4):1604-7.

87. Hanley B, Naresh KN, Roufosse C, Nicholson AG, Weir J, Cooke GS, et al. Histopathological findings and viral tropism in UK patients with severe fatal COVID-19: a post-mortem study. Lancet Microbe. 2020;1(6):e245-53.

88. Wheatland R. Molecular mimicry of ACTH in SARS - implications for corticosteroid treatment and prophylaxis. Med Hypotheses. 2004;63(5):855-62.

89. Leow MK, Kwek DS, Ng AW, Ong KC, Kaw GJ, Lee LS. Hypocortisolism in survivors of severe acute respiratory syndrome (SARS). Clin Endocrinol (Oxf). 2005;63(2):197-202.

90. Veronese N, Demurtas J, Yang L, Tonelli R, Barbagallo M, Lopalco P, et al. Use of Corticosteroids in Coronavirus Disease 2019 Pneumonia: A Systematic Review of the Literature. Front Med (Lausanne). 2020;7:170.

91. Strehl C, Ehlers L, Gaber T, Buttgereit F. GlucocorticoidsAll-Rounders Tackling the Versatile Players of the Immune System. Front Immunol. 2019;10:1744.

92. Gruver-Yates AL, Quinn MA, Cidlowski JA. Analysis of glucocorticoid receptors and their apoptotic response to dexamethasone in male murine B cells during development. Endocrinology. 2014;155(2):463-74.

93. Fedor ME, Rubinstein A. Effects of long-term low-dose corticosteroid therapy on humoral immunity. Ann Allergy Asthma Immunol. 2006;97(1):113-6.

94. Hottinger AF, George AC, Bel M, Favet L, Combescure C, Meier S, et al. A prospective study of the factors shaping antibody responses to the AS03-adjuvanted influenza A/H1N1 vaccine in cancer outpatients. Oncologist. 2012;17(3):436-45.

95. Fischer L, Gerstel PF, Poncet A, Siegrist CA, Laffitte E, Gabay $\mathrm{C}$, et al. Pneumococcal polysaccharide vaccination in adults undergoing immunosuppressive treatment for inflammatory diseases-a longitudinal study. Arthritis Res Ther. 2015;17:151.

96. Yildiz N, Sever L, Kasapcopur O, Cullu F, Arisoy N, Caliskan $\mathrm{S}$. Hepatitis B virus vaccination in children with steroid sensitive nephrotic syndrome: immunogenicity and safety? Vaccine. 2013;31(33):3309-12.

97. Herron A, Dettleff G, Hixon B, Brandwin L, Ortbals D, Hornick $\mathrm{R}$, et al. Influenza vaccination in patients with rheumatic diseases. Safety and efficacy JAMA. 1979;242(1):53-6.

98. Kubiet MA, Gonzalez-Rothi RJ, Cottey R, Bender BS. Serum antibody response to influenza vaccine in pulmonary patients receiving corticosteroids. Chest. 1996;110(2):367-70.

99. Elkayam O, Amir S, Mendelson E, Schwaber M, Grotto I, Wollman J, et al. Efficacy and safety of vaccination against pandemic 2009 influenza A (H1N1) virus among patients with rheumatic diseases. Arthritis Care Res (Hoboken). 2011;63(7):1062-7.

100. Chakravarthy K, Strand N, Frosch A, Sayed D, Narra LR, Chaturvedi $\mathrm{R}$, et al. Recommendations and Guidance for Steroid Injection
Therapy and COVID-19 Vaccine Administration from the American Society of Pain and Neuroscience (ASPN). J Pain Res. 2021;14:623-9.

101. Sytsma TT, Greenlund LK, Greenlund LS. Joint Corticosteroid Injection Associated With Increased Influenza Risk. Mayo Clin Proc Innov Qual Outcomes. 2018;2(2):194-8.

102. Miller DC, Patel J, Gill J, Mattie R, Saffarian M, Schneider BJ, et al. Corticosteroid Injections and COVID-19 Infection Risk. Pain Med. 2020;21(8):1703-6.

103. Lee H, Punt JA, Miller DC, Nagpal A, Smith CC, Sayeed Y, et al. Do Corticosteroid Injections for the Treatment of Pain Influence the Efficacy of mRNA COVID-19 Vaccines? Pain Med. 2021.

104. Park CL, Frank AL, Sullivan M, Jindal P, Baxter BD. Influenza vaccination of children during acute asthma exacerbation and concurrent prednisone therapy. Pediatrics. 1996;98(2 Pt 1):196-200.

105. Fairchok MP, Trementozzi DP, Carter PS, Regnery HL, Carter ER. Effect of prednisone on response to influenza virus vaccine in asthmatic children. Arch Pediatr Adolesc Med. 1998;152(12):1191-5.

106. Bergmann M, Freisl M, Hartmann K, Speck S, Truyen U, Zablotski Y, et al. Antibody Response to Canine Parvovirus Vaccination in Dogs with Hyperadrenocorticism Treated with Trilostane. Vaccines (Basel). 2020;8(3).

107. Boyarsky BJ, Werbel WA, Avery RK, Tobian AAR, Massie AB, Segev DL, et al. Immunogenicity of a Single Dose of SARSCoV-2 Messenger RNA Vaccine in Solid Organ Transplant Recipients. JAMA. 2021.

108. Jackson LA, Anderson EJ, Rouphael NG, Roberts PC, Makhene $\mathrm{M}$, Coler RN, et al. An mRNA Vaccine against SARS-CoV-2 Preliminary Report. N Engl J Med. 2020;383(20):1920-31.

109. Walsh EE, Frenck RW Jr, Falsey AR, Kitchin N, Absalon J, Gurtman A, et al. Safety and Immunogenicity of Two RNA-Based Covid-19 Vaccine Candidates. N Engl J Med. 2020;383(25):2439-50.

110. Recommendations of the Advisory Committee on Immunization Practices (ACIP). use of vaccines and immune globulins for persons with altered immunocompetence. MMWR Recomm Rep. 1993;42(RR-4):1-18.

111. National Center for I, Respiratory D. General recommendations on immunization --- recommendations of the Advisory Committee on Immunization Practices (ACIP). MMWR Recomm Rep. 2011;60(2):1-64.

112. Schulze-Koops H, Specker C, Skapenko A. Vaccination of patients with inflammatory rheumatic diseases against SARSCoV-2: considerations before widespread availability of the vaccines. RMD Open. 2021;7(1).

113. Brenner EJ, Ungaro RC, Colombel JF, Kappelman MD. IBD in the COVID-19 era: the value of international collaboration. Lancet Gastroenterol Hepatol. 2020;5(10):887-8.

114. Braun LT, Riester A, Osswald-Kopp A, Fazel J, Rubinstein G, Bidlingmaier M, et al. Toward a Diagnostic Score in Cushing's Syndrome. Front Endocrinol (Lausanne). 2019;10:766.

115. Gokosmanoglu F, Guzel A, Kan EK, Atmaca H. Increased prevalence of obstructive sleep apnea in patients with Cushing's syndrome compared with weight- and age-matched controls. Eur J Endocrinol. 2017;176(3):267-72.

116. Wu C, Chen X, Cai Y, Xia J, Zhou X, Xu S, et al. Risk Factors Associated With Acute Respiratory Distress Syndrome and Death in Patients With Coronavirus Disease 2019 Pneumonia in Wuhan. China JAMA Intern Med. 2020;180(7):934-43.

117. Delivanis DA, Iniguez-Ariza NM, Zeb MH, Moynagh MR, Takahashi N, McKenzie TJ, et al. Impact of hypercortisolism on skeletal muscle mass and adipose tissue mass in patients with adrenal adenomas. Clin Endocrinol (Oxf). 2018;88(2):209-16.

118. Rottoli M, Bernante P, Belvedere A, Balsamo F, Garelli S, Giannella M, et al. How important is obesity as a risk factor 
for respiratory failure, intensive care admission and death in hospitalised COVID-19 patients? Results from a single Italian centre. Eur J Endocrinol. 2020;183(4):389-97.

119. De Giorgio MR, Di Noia S, Morciano C, Conte D. The impact of SARS-CoV-2 on skeletal muscles. Acta Myol. 2020;39(4):307-12.

120. Dhingra A, Ganie MA, Dharmshaktu P, Chakraborty S, Jyotsna VP, Gupta N. Pattern of Lipid Abnormalities Among South Asian Indians With Cushing's Syndrome and the Short Term Impact of Surgical Correction of Hypercortisolism. Horm Metab Res. 2019;51(5):309-14.

121. Zuin M, Rigatelli G, Bilato C, Cervellati C, Zuliani G, Roncon L. Dyslipidaemia and mortality in COVID-19 patients - a metaanalysis. QJM. 2021.
122. Pivonello R, Simeoli C, De Martino MC, Cozzolino A, De Leo $\mathrm{M}$, Iacuaniello D, et al. Neuropsychiatric disorders in Cushing's syndrome. Front Neurosci. 2015;9:129.

123. Barcella CA, Polcwiartek C, Mohr GH, Hodges G, Sondergaard $\mathrm{K}$, Bang $\mathrm{C}$, et al. Severe mental illness is associated with increased mortality and severe course of COVID-19. Acta Psychiatr Scand. 2021.

124. Strausz S, Kiiskinen T, Broberg M, Ruotsalainen S, Koskela J, Bachour A, et al. Sleep apnoea is a risk factor for severe COVID19. BMJ Open Respir Res. 2021;8(1).

Publisher's Note Springer Nature remains neutral with regard to jurisdictional claims in published maps and institutional affiliations. 